\title{
Pre-heating effects on extrusion force, stickiness and packability of resin-based composite
}

DOI:

10.1016/j.dental.2019.08.101

\section{Document Version}

Accepted author manuscript

Link to publication record in Manchester Research Explorer

\section{Citation for published version (APA):}

Yang, J., Silikas, N., \& Watts, D. C. (2019). Pre-heating effects on extrusion force, stickiness and packability of resin-based composite. Dental Materials, 35(11), 1594-1602. https://doi.org/10.1016/j.dental.2019.08.101

\section{Published in:}

Dental Materials

\section{Citing this paper}

Please note that where the full-text provided on Manchester Research Explorer is the Author Accepted Manuscript or Proof version this may differ from the final Published version. If citing, it is advised that you check and use the publisher's definitive version.

\section{General rights}

Copyright and moral rights for the publications made accessible in the Research Explorer are retained by the authors and/or other copyright owners and it is a condition of accessing publications that users recognise and abide by the legal requirements associated with these rights.

\section{Takedown policy}

If you believe that this document breaches copyright please refer to the University of Manchester's Takedown Procedures [http://man.ac.uk/04Y6Bo] or contact uml.scholarlycommunications@manchester.ac.uk providing relevant details, so we can investigate your claim.

\section{OPEN ACCESS}




\section{Pre-heating effects on extrusion force, stickiness and packability of resin-based composite.}

Jiawei Yang ${ }^{1}$, Nikolaos Silikas ${ }^{1}$, David C. Watts ${ }^{1,2}$

1. Dentistry, School of Medical Sciences, University of Manchester, Manchester, UK

2. Photon Science Institute, University of Manchester, Manchester, UK

Short Title: Preheating resin-based composite.

Corresponding authors:

Prof. Nikolaos Silikas

University of Manchester, School of Medical Sciences

Coupland 3 Building, Oxford Road, Manchester M13 9PL, UK

Email: nick.silikas@manchester.ac.uk

Prof. David C Watts

University of Manchester, School of Medical Sciences

Coupland 3 Building, Oxford Road, Manchester M13 9PL, UK

Email: david.watts@manchester.ac.uk 


\begin{abstract}
Objectives. To measure temperature effects on stickiness and packability of representative resin-based composites and the effect of pre-heating time on pre-cure properties of Viscalor, including extrusion force.
\end{abstract}

Methods. Five resin-based composites (RBC) and an additional RBC, Viscalor, used with a Caps Warmer (VOCO, Germany) were studied. The extrusion force (N) and extruded mass (g) were measured from Viscalor compules heated in T3 mode for $30 \mathrm{~s}$ (T3-30s) and 3 min (T3-3min). For stickiness and packability measurements, RBCs were packed into a brass cylindrical cavity controlled at 22 and $37^{\circ} \mathrm{C}$. A flat-ended probe was lowered into the RBC pastes at constant speed. Stickiness: $\mathrm{F}_{\max }(\mathrm{N})$ and $\mathrm{W}_{\mathrm{s}}(\mathrm{N} \mathrm{mm})$, and packability: $\mathrm{F}_{\mathrm{p}}(\mathrm{N})$, were measured. Viscalor was LED photo-cured at $1,200 \mathrm{~mW} / \mathrm{cm}^{2}$ for $40 \mathrm{~s}$. The degrees of conversion at $5 \mathrm{~min}$ and $24 \mathrm{~h}$ post cure ( $\mathrm{DC}_{5 \min }$ and $\mathrm{DC}_{24 \mathrm{~h}}$ ) of Viscalor (no heat, T3-30s and T3-3min) were measured by ATR-FTIR. Data were analysed by one-way ANOVA, independent T-test and Tukey post-hoc tests $(\mathrm{p}<0.05)$.

Results. The maximum temperature of the Caps Warmer, in T3 mode, reached $68^{\circ} \mathrm{C}$ in 20 min. Viscalor temperatures of $34.5^{\circ} \mathrm{C}$ and $60.6^{\circ} \mathrm{C}$ were recorded after $30 \mathrm{~s}$ and 3 min preheating, respectively. Pre-heating significantly reduced extrusion force and increased extruded mass, especially after 3 min. $R B C s$ varied in $F_{\max }, W_{s}$ and $F_{p}(p<0.05)$. Temperature also affected $\mathrm{F}_{\max }(\mathrm{p}=0.000), \mathrm{W}_{\mathrm{s}}(\mathrm{p}=0.002)$ and $\mathrm{F}_{\mathrm{p}}(\mathrm{p}=0.000)$. Pre-heating Viscalor for either $30 \mathrm{~s}$ or $3 \mathrm{~min}$ did not increase the post-cure DC at either $5 \mathrm{~min}$ or $24 \mathrm{~h}$, relative to no pre-heating $(\mathrm{p}>0.05)$.

Significance. The composites varied to an extent in stickiness and packability but the overall magnitudes remained within a clinically acceptable range. Pre-heating was beneficial in placement of Viscalor and caused no adverse effects through premature polymerization.

Keywords: resin composite; extrusion force; handling properties; stickiness; preheating; degree of conversion. 


\section{Introduction}

Resin-based composites (RBCs) are designed and manipulated with suitable esthetic and physico-chemical properties to match the tooth structure. They can be fabricated in a range of consistencies and are therefore widely used as direct restorative materials in dentistry [13]. The maximum obtained properties and longevity of composites are dependent on the clinician's skill level and operating conditions $[4,5]$. Thus, 'technique sensitivity' should be reduced for good marginal integrity and successful restoration [6]. To avoid the formation of voids and gaps, both insertion technique and adaptation of composites need improvement [4]. The successful clinical handling and placement mainly depends on suitable pre-cure properties of composites that are determined by material composition and viscosity [7].

Pre-cure handling properties, such as flowability, stickiness, ease of placement and adaptation to cavity walls affect product selection for clinical restoration $[8,9]$. Stickiness the adhesion force between two contacted surfaces - has been studied previously [8, 10-12]. In a related field, the Avery Adhesive Test (AAT) with a spherical probe was used to study pressure-sensitive adhesives (PSA) [13]. In 2003, a method was reported using a flat-ended stainless-steel probe $[8,10]$. Clinically, the relationship between stickiness to tooth cavity and stickiness to instruments should be well balanced $[8,10,14]$. High stickiness to instruments may result in difficult placement and more porosities/gaps may occur during restoration $[8,10]$. RBCs with adequate consistency and packability are important for adapting to the tooth cavity and optimizing approximal contact areas [10, 15]. Tyas et al. designed a method to assess consistency of unset composites [10, 15]. They placed materials in an $8 \mathrm{~mm} \times 8 \mathrm{~mm}$ cylindrical mould and pressed with a flat-ended glass rod demonstrating the high consistency of RBCs with increased filler content [9, 15].

RBCs exhibit both viscous and elastic properties against the applied force and the rheological nature of pre-cure RBCs affects their handling properties $[8,10]$. Viscosity directly relates to material's handling properties, operating time and quality of restoration $[10,14,16,17]$. Viscosity decreases with temperature according to the Arrhenius Equation:

$$
\eta=\mathrm{A} e^{E_{a} / R T}
$$

where $\eta, A, E_{a}, R$ and $T$ represent viscosity, pre-exponential factor, activation energy for flow, universal gas constant and absolute temperature, respectively [16]. Viscosity also tends to increase exponentially with filler content $[8,17]$. 
Bis-GMA has higher viscosity than other dimethacrylates, resulting in low degree of conversion (DC) and requiring diluent monomers to facilitate filler particle incorporation $[2,18-22]$. High viscosity of highly-filled RBCs may cause insufficient adaptation to the cavity preparation, poor marginal integrity, and final restoration failure [23].

There are several possible strategies to achieve good cavity adaptation via reduced viscosity. Ideally, materials should flow into every corner of the cavity but not flow after removing the applied force $[8,10]$. High viscous RBC pastes are hard to extrude from the syringe or compule, which may lead to macroscopic voids/porosities during manipulation $[8,16,23]$ and this was a major reason for developing flowable composites [24-26].

The SonicFill system (Kerr, USA), contains a highly-filled resin matrix including special viscosity modifiers that respond to ultrasonic energy (UE) and reduce the viscosity by 87 $\%$. Once UE is stopped, the viscosity returns to high levels, suitable for carving and contouring [27].

Several studies have evaluated pre-heating RBCs before placement [25, 28, 29]. Preheating makes highly-packed RBCs more fluid and easier to manipulate, without compromising their superior mechanical properties [30]. But after pre-heating the elevated temperature may cause thermal damage to the pulp [31]. The pulp has a normal temperature of $34-35^{\circ} \mathrm{C}$, and with temperature increases ranging from 5.5 to $16^{\circ} \mathrm{C}$, the possibility of pulp necrosis may increase from $15 \%$ to $100 \%$ [32].

Existing pre-heating devices, such as Calset heater (AdDent Inc., Danbury, CT, USA) and ENA heat (Micerium, Avegno, Italy), have operating temperature ranges of $37-68^{\circ} \mathrm{C}$ [7, 26, 32-34].

A new pre-heating RBC, Viscalor, has been designed for use with a Caps Warmer device (VOCO, Germany). This has three working modes (T1, T2 and T3) to cover the temperature range $37-68{ }^{\circ} \mathrm{C}$. The objectives of this study were to measure pre-cure properties including stickiness and packability of representative RBCs at different temperatures, and determine the effect of pre-heating time on pre-cure properties of Viscalor, including extrusion forces. The Null Hypotheses were:

(1) composites did not vary in stickiness and packability at different temperatures, and (2) pre-heating period had no effect on Viscalor's post-cure DC\% measured at either 5 min or $24 \mathrm{~h}$. 


\section{Materials and methods}

Five commercial RBCs and an additional RBC: Viscalor used with a Caps Warmer (VOCO, Germany), were studied. The manufacturers' information is shown in Table 1.

A type-K thermocouple was inserted into the Caps Warmer (Fig. S1) to characterize its temperature profile in T3 mode. When it reached its maximum temperature, Viscalor compules were put into the Caps Warmer for $30 \mathrm{~s}$ and 3 min pre-heating times. Temperature was measured via a type-K thermocouple inside the compule. After preheating, the compule was removed from the Caps Warmer.

The extrusion force (N) of Viscalor from both full and half-full compules was measured using a modified compule dispenser and a universal testing machine (Zwick/ Roell Z020, Leominster, UK) (Fig. S2). Viscalor was pre-heated before measurement using the Caps Warmer in T3 mode for $30 \mathrm{~s}$ (T3-30s) and $3 \mathrm{~min}$ (T3-3min). Compressive force was applied at $1 \mathrm{~mm} / \mathrm{s}$ until either an upper force limit of $150 \mathrm{~N}$ or the maximum extrusion distance of $10 \mathrm{~mm}$ was reached $(\mathrm{n}=3)$. The mass of extruded composite $(\mathrm{g})$ was also measured.

A Texture Analyzer (Fig. S3) (TA.XT2i, Stable Micro Systems, Godalming, UK) was used to measure stickiness: via maximum separation force $\left(F_{\max }, N\right)$ and work of probeseparation $\left(\mathrm{W}_{\mathrm{s}}, \mathrm{N} \mathrm{mm}\right)$, and packability: maximum packing force $\left(\mathrm{F}_{\mathrm{p}}, \mathrm{N}\right)$. Force was applied to a flat-ended cylindrical stainless-steel probe $(\varphi=6 \mathrm{~mm})$. A thermostatically controlled mold at $22{ }^{\circ} \mathrm{C}$ and $37^{\circ} \mathrm{C}$ with a cylindrical cavity $(\phi=7 \mathrm{~mm}$, depth $=5 \mathrm{~mm})$ was fixed to a stand (Fig. 1). Composite paste was carefully packed into the cavity (n=5).

For stickiness measurement, during the 'bonding' phase, the probe was lowered into the surface of unset composite with a pre-test speed of $0.50 \mathrm{~mm} / \mathrm{s}$. When a 'trigger' force of $0.05 \mathrm{~N}$ was registered, data acquisition commenced at rate of $400 \mathrm{p} / \mathrm{s}$ until a compressive force of $1 \mathrm{~N}$ was recorded, and held constant for $1 \mathrm{~s}$. In the subsequent 'debonding' phase, the probe was raised vertically at $2 \mathrm{~mm} / \mathrm{s}$. Since the unset composite paste adhered to the probe, it elongated and exerted a tensile force as the probe ascended. With further elongation, tensile stress increased until it reached the interfacial strength and the composite paste separated from the probe.

Packability measurement used a similar experimental setup. Before measurement, the probe position was set $10 \mathrm{~mm}$ above the cavity. The probe was lowered into the surface of unset composite at $0.50 \mathrm{~mm} / \mathrm{s}$. When a 'trigger' force of $0.05 \mathrm{~N}$ was registered, data acquisition 
commenced until the probe penetrated $2 \mathrm{~mm}$. Then the probe ascended vertically at 2 $\mathrm{mm} / \mathrm{s}$.

Fourier Transform Infrared (FTIR) Spectroscopy with an attenuated total reflectance (ATR) device (ALPHA II FTIR Spectrometer, Bruker Optik GmbH) was used to measure the DC\% of Viscalor syringe/compule (no heat, T3-30s and T3-3min) at 5 min and 24 h postcure. A background reading was collected between 400 to $4000 \mathrm{~cm}^{-1}$ using 32 scans at a resolution of $4 \mathrm{~cm}^{-1}$. Composite paste was placed in an acetal mold (4 mm diameter $\mathrm{x} 2$ mm thickness) directly on top of the ATR crystal. A Mylar strip and a glass slide were pressed onto the mold to remove air bubbles and excess paste. The spectrum of uncured Viscalor was collected. Photo-cure was achieved using an Elipar S10 LED unit (3M ESPE, USA) of mean irradiance $1200 \mathrm{~mW} / \mathrm{cm}^{2}$ for $40 \mathrm{~s}$ at zero distance from the top surface. Then the spectrophotometer's screw was applied to fix the cured specimen tightly on the reading crystal. The spectrum of the 5 min post-cured composite was collected. Then the spectra were acquired continually in real time for $24 \mathrm{~h}$ to obtain DC\% at $24 \mathrm{~h}$ post-cure.

The spectral region between $1600-1700 \mathrm{~cm}^{-1}$ was selected to identify the heights of the aliphatic $\mathrm{C}=\mathrm{C}$ absorbance peak at $1637 \mathrm{~cm}^{-1}$ and the aromatic $\mathrm{C}=\mathrm{C}$ absorbance peak at $1608 \mathrm{~cm}^{-1}$. The DC\% was calculated as:

$$
D C \%=1-\frac{\left(H_{1637 \mathrm{~cm}^{-1}} / H_{1608 \mathrm{~cm}^{-1}}\right)_{\text {cured }}}{\left(H_{1637 \mathrm{~cm}^{-1}} / H_{1608 \mathrm{~cm}^{-1}}\right)_{\text {uncured }}} \times 100 \%
$$

where $H_{1637 \mathrm{~cm}^{-1}}$ is the height of aliphatic $\mathrm{C}=\mathrm{C}$ peak, $H_{1608 \mathrm{~cm}^{-1}}$ is the height of aromatic $\mathrm{C}=\mathrm{C}$ peak, respectively.

Data were entered into statistical software (SPSS, SPSS Inc., Illinois, USA) and analysed using one-way ANOVA test, independent T-test and Tukey post-hoc tests $(\mathrm{p}<0.05)$. Homogeneity of variables was calculated using the Kruskal-Wallis Test $(\mathrm{p}<0.05)$.

\section{Results}

Fig. 2 shows representative temperature/time profiles of the Caps Warmer in T3 mode and the Viscalor temperatures following different pre-heating times. The Caps Warmer in T3 mode reached $68{ }^{\circ} \mathrm{C}$ after ca. $20 \mathrm{~min}$. Composite temperature increases of $14.3{ }^{\circ} \mathrm{C}$ and 39.1 ${ }^{\circ} \mathrm{C}$ were recorded after $30 \mathrm{~s}$ and $3 \mathrm{~min}$ pre-heating, respectively. After removed from the Caps Warmer, composite temperature gradually returned to ambient temperature. 
The extrusion force $(\mathrm{N})$ and extruded mass $(\mathrm{g})$ of full or half-full Viscalor compules (for no heat, T3-30s and T3-3min) are shown in Table 2 and Figs. 3 and 4. The extrusion force varied with pre-heating conditions, with 3 min heating giving the lowest extrusion force $(\mathrm{p}=0.000)$. Partial usage of the compule had no significant influence on the measured extrusion force $(\mathrm{p}=0.866)$. Viscalor compules with no heating yielded the lowest mass of extruded composite ( $\mathrm{p}=0.000$ ). Half-used Viscalor compules (no heat, T3-30s and T3$3 \mathrm{~min})$ showed slightly higher extruded mass, in a fixed period, than full compules $(\mathrm{p}<0.05)$.

Table. 3 and Fig. $5-7$ show stickiness $\left(F_{\max }\right.$ and $\left.\mathrm{W}_{\mathrm{s}}\right)$ and packability $\left(\mathrm{F}_{\mathrm{p}}\right)$ data for different composites at 22 and $37{ }^{\circ} \mathrm{C} . \mathrm{F}_{\max }, \mathrm{W}_{\mathrm{s}}$ and $\mathrm{F}_{\mathrm{p}}$ ranged from 1.50 to $3.28 \mathrm{~N}$, from 0.79 to 4.69 $\mathrm{N}$ mm and from 10.79 to $41.56 \mathrm{~N}$, respectively. Different RBCs varied in $\mathrm{F}_{\max }(\mathrm{p}=0.000)$, $\mathrm{W}_{\mathrm{s}}(\mathrm{p}=0.000)$ and $\mathrm{F}_{\mathrm{p}}(\mathrm{p}=0.032)$. Temperature also had a significant effect on $\mathrm{F}_{\max }$ $(p=0.000), W_{s}(p=0.002)$ and $F_{p}(p=0.000)$, for which temperature rise reduced $F_{\max }$ and $F_{p}$, but increased $\mathrm{W}_{\mathrm{s}}$.

Fig. 8 represents real-time DC\% vs. time during 24 h post-polymerization of Viscalor syringe/compule (no heat, T3-30s and T3-3min). Real-time DC\% curves of Viscalor syringe and compule develop over $24 \mathrm{~h}$ with a similar trend. Table 4 and Fig. 9 report the $\mathrm{DC} \%$ at 5 min and $24 \mathrm{~h}$ post-cure $\left(\mathrm{DC}_{5 \mathrm{~min}}\right.$ and $\mathrm{DC}_{24 \mathrm{~h}}$ ) of Viscalor syringe/compule (no heat, T3-30s and T3-3mins). After 24 h, DC\% increased to approximately $60 \%$. There were no significant differences in DC\% results between syringe and compule ( $p>0.05)$. Precure heating of Viscalor syringe/compule for either $30 \mathrm{~s}$ or $3 \mathrm{~min}$ in a $68^{\circ} \mathrm{C}$ Caps Warmer did not increase the post-cure DC\% at either $5 \mathrm{~min}$ or $24 \mathrm{~h}$, compared to data for no preheating $(\mathrm{p}>0.05)$.

\section{Discussion}

Dental RBCs are designed to exhibit good mechanical properties and esthetics after restoration, but their pre-cure properties, including stickiness and packability, mainly affect the clinical handling and placement [35]. These handling properties depend upon the inherent material characteristics and rheological nature of composites [14]. Hence, this study investigated extrusion force, stickiness and packability at different temperatures and evaluated post-cure DC\% at $5 \mathrm{~min}$ and $24 \mathrm{~h}$ for Viscalor after different pre-heating times. Thus, the first null hypothesis was rejected and the second null hypothesis was accepted. 
Regardless of pre-heating time, no significant change in DC\% of Viscalor was measured $(\mathrm{p}>0.05)$.

The thermal properties and heating rates of both Caps Warmer and pre-heated Viscalor were previously unreported. Thus, temperature profiles of Caps Warmer in the T3 mode and Viscalor following different pre-heating periods were first characterized. Results demonstrated the efficacy of the Caps Warmer since it reached the stated preset temperature of $68{ }^{\circ} \mathrm{C}$ after about $20 \mathrm{~min}$. When heating was stopped, a slight temperature rise of $2.09{ }^{\circ} \mathrm{C}$ and $0.35{ }^{\circ} \mathrm{C}$ was found, respectively. During pre-heating, thermal energy diffused gradually through the container (compule or syringe) into the composite.

With temperature rise the viscosity of Viscalor reduced, but its flowability was still somewhat less than certain flowable RBCs at room temperature [35]. After 3 min preheating, Viscalor had a lower internal temperature than the maximum temperature of the Caps Warmer in T3 mode $\left(68^{\circ} \mathrm{C}\right)$. This corresponds to previous studies where pre-heated composites were cooler than the pre-set temperature of heating devices. Thus reduced pulp temperature changes may ensue [32]. Reduced composite temperature rises also relate to filler properties since inert inorganic particles only absorb small amounts of thermal energy during heating $[35,36]$. The high filler content of Viscalor implies a low proportion of resin matrix and consequently a low temperature rise [36]. Different filler contents result in different temperature/time profiles. The temperature of Viscalor (T3-3min) decreased to 37 ${ }^{\circ} \mathrm{C}$ within 3 min after removed from the Caps Warmer. To ensure minimal temperature drop and optimal performance, clinicians should work rapidly during manipulation of preheated composites.

To quantify the effect of pre-heating on Viscalor's flowability, the extrusion force $(\mathrm{N})$ and extruded mass (g) were measured for both full and half-used Viscalor compules. Results showed the beneficial effects of a longer pre-heating period, in which extrusion force reduced and extruded mass increased. This confirmed that 3 min pre-heating did increase the flowability of Viscalor leading to easy extrusion and a sufficient mass of extruded composite.

Stickiness measurements were based on previous studies on the effects of temperature and composite composition [8-10,14]. Generally, there are two types of force/displacement plots (Type I and Type II), in which Type I is more commonly observed (Fig. S4). A Type I plot has a single peak, whereas a Type II plot has a primary peak followed by a secondary 
peak [14]. The peak height $\left(\mathrm{F}_{\max }\right)$ is the maximum tensile force during 'debonding'. The work of probe-separation $\left(\mathrm{W}_{\mathrm{s}}\right)$ is the integrated area under the curve [10].

The force/displacement profiles observed were combined responses of RBC paste viscoelasticity and interfacial behaviour between the probe and paste $[8,13]$. $F_{\max }$ mainly depends on the wettability of the paste, its resistance against the debonding force, and the roughness of both probe and paste $[8,13,14]$. Other factors, such as temperature and viscoelastic properties of the paste also affect $F_{\max }[14] . \mathrm{W}_{\mathrm{s}}$ depended on the shear characteristics of the pastes, which relates to their molecular entanglements $[8,13,14]$. In the present stickiness results, Admira Fusion exhibited the highest $\mathrm{F}_{\max }$ and $\mathrm{W}_{\mathrm{s}}$ at both 22 and $37{ }^{\circ} \mathrm{C}$. According to previous studies, high filler loading tends to produce low stickiness [8, 17] as it hinders composite flowability and creates high viscosity [37]. Admira Fusion, Viscalor and Harmonize have high filler content (84 wt.\%, 83 wt.\% and $81 \mathrm{wt} . \%$, respectively) and their $F_{\max }$ varied with filler content. However, they did not exhibit particularly low stickiness, as expected. This may be due to their matrix compositions. Admira Fusion is a ceramic-based RBC, in which ORMOCERs function as the matrix system [38-40]. Nanoparticles and glass ceramic particles are firmly embedded in the ORMOCER matrix [41]. The ART (Adaptive Response Technology) filler system in Harmonize acts as a rheological modifier.

Although containing relatively high filler loading, Filtek Supreme Ultra (78.5 wt.\%) showed higher $\mathrm{F}_{\max }$ and $\mathrm{W}_{\mathrm{s}}$ compared to TPH LV (75.5 wt.\%) and Tetric EvoCeram (75 wt.\%). This may be due to both TEGDMA and bisphenol-A epoxylated dimethacrylate (bis-EMA) within its matrix system [16, 17]. Previous studies have noted that the presence/absence of hydrogen bonding significantly affects viscosity. Bis-EMA, lacks two hydroxyl groups (-OH) in its chemical structure, compared to bis-GMA, which reduces viscosity [42]. But, with a low-viscous matrix system, TPH LV and Tetric EvoCeram still showed low $\mathrm{F}_{\max }$ and $\mathrm{W}_{\mathrm{s}}$ possibly related to their filler characteristics. Many previous studies established that all compositional variables affect RBC rheological and handling properties: resin matrix, filler particle content, shape, size and distribution, silane surface treatment, interlocking between particles and other interfacial interactions between resin matrix and filler [30,43]. Generally, increasing filler loading and using smaller, irregularshaped particles increases viscosity [30, 44]. Filler particle sizes of TPH LV (1.35 $\mu \mathrm{m})$ [45] and Tetric EvoCeram (40 nm - $3 \mu \mathrm{m})$ [46] are lower than those in Filtek Supreme Ultra (0.6 $-10 \mu \mathrm{m})$ [47]. For a similar filler loading, more particles means higher surface area, more matrix/particle interactions and thus higher viscosity [17]. TPH LV and Tetric EvoCeram had low stickiness. Different filler morphologies - following the sequence: round, grains, 
plates and rods - reduce viscosity of RBCs [17]. Silane surface treatment may slightly lubricate irregular particles and reduce viscosity [17]. However, in this study, the lack of filler morphology information limits the discussion.

For packability measurements, compressive force $(\mathrm{N})$ was plotted against probe displacement (mm) (Fig. S5). Fp reduced with decreased filler loading. Admira Fusion and TPH LV had the highest and lowest $\mathrm{F}_{\mathrm{p}}$ values at both 22 and $37{ }^{\circ} \mathrm{C}$, respectively.

In addition to paste composition, temperature also affected stickiness and packability: reducing $\mathrm{F}_{\max }$ and $\mathrm{F}_{\mathrm{p}}$, but increasing $\mathrm{W}_{\mathrm{s}}$. Temperature increases the mobility of matrix monomers. Low viscous $\mathrm{RBCs}$ are more fluid so temperature further reduces $\mathrm{F}_{\mathrm{p}}$. Composite pastes bond more easily to the probe, increasing $\mathrm{F}_{\max }$ and $\mathrm{W}_{\mathrm{s}}[8,29]$. However, some studies found that $\mathrm{F}_{\max }$ and $\mathrm{W}_{\mathrm{s}}$ may be lower at high temperature $[9,11,14,17]$. Since segmental movement is greater at high temperature, matrix monomers are insufficiently resistant to slippage of internal components. This factor tends to reduce $F_{\max }$ and $\mathrm{W}_{\mathrm{s}}[9,11$, $14,17]$.

Viscalor (no heat) showed generally comparable $\mathrm{F}_{\max }, \mathrm{W}_{\mathrm{s}}$ and $\mathrm{F}_{\mathrm{p}}$ to the other investigated RBC pastes. Different pre-heating times had significant influence on $F_{\max }, W_{s}$ and $F_{p}$ at either 22 or $37^{\circ} \mathrm{C}(\mathrm{p}<0.005)$, except for $\mathrm{F}_{\max }$ at $37^{\circ} \mathrm{C}(\mathrm{p}=0.884)$. Composite temperature can reduce rapidly to the ambient physiological level after removed from a pre-heating device [7, 29, 32]. Thus, pre-heated Viscalor (T3-30s and T3-3min) inserted into the brass cavity showed similar $\mathrm{F}_{\max }$ results to Viscalor (no heat) at $37{ }^{\circ} \mathrm{C}$ due to the similar composite temperature. However, Viscalor's $\mathrm{W}_{\mathrm{s}}$ changed significantly with different preheating times. So evidently $\mathrm{W}_{\mathrm{s}}$ was more sensitive than $\mathrm{F}_{\max }$ to changes in elongation and arguably more appropriate to describe stickiness [14].

Moderate temperature rise after pre-heating generates greater mobility of monomer free radicals - as and when they are generated by photo-initiation. The temperature rise delays auto-deceleration during polymerization and leads to the increased DC\% [7, 26, 29, 32, 48, 49]. Higher monomer conversion has been observed after pre-heating composites at $54{ }^{\circ} \mathrm{C}$, however, high polymerization shrinkage also occur with high DC\% [7, 26, 50]. But, after $30 \mathrm{~s}$ pre-heating, $\mathrm{F}_{\mathrm{p}}$ decreased slightly at either 22 or $37^{\circ} \mathrm{C}$.

To further identify the effect of pre-heating time on pre-cure stickiness and packability of Viscalor, DC\% was measured. After $24 \mathrm{~h}$ at $37^{\circ} \mathrm{C}$, DC\% increased [48, 49]. The use of Viscalor syringe or compule had no significant influence on $\mathrm{DC}_{5 \min }$ and $\mathrm{DC}_{24 \mathrm{~h}}$. Real-time DC\% curves of both Viscalor syringe and compule specimens increased similarly. 
Different pre-heating time had no significant effect on Viscalor syringe/compule DC\% either measured after 5 min or $24 \mathrm{~h}$. Generally, temperature rise has a positive effect on $\mathrm{DC} \%$, since temperature rise aids polymer chain propagation.

Three minutes pre-heating did not affect the DC\% of Viscalor syringe/compule specimens.

This suggests that no premature monomer curing occurred.

\section{Conclusions}

Within the limitations of this study, the following conclusions are drawn:

1) The Caps Warmer exhibited good efficacy as a pre-heating device: pre-heated Viscalor showed greatly reduced extrusion force and increased flowability, especially after the longer pre-heating time (3 $\mathrm{min})$.

2) The RBC pastes varied to a statistically significant but limited extent in stickiness and packability. But, their overall magnitudes remained within what may be considered a clinically acceptable range.

3) Pre-heating had no adverse effects on Viscalor through any thermal activation causing premature polymerization.

\section{References}

1. Sakaguchi RL, Powers JM. Craig's Restorative Dental Materials-E-Book: Elsevier Health Sciences; 2012.

2. Anusavice KJ, Shen C, Rawls HR. Phillips' science of dental materials: Elsevier Health Sciences; 2013.

3. Antoniac IV. Handbook of Bioceramics and Biocomposites: Springer Berlin Heidelberg, New York; 2016.

4. Nedeljkovic I, Teughels W, De Munck J, Van Meerbeek B, Van Landuyt KL. Is secondary caries with composites a material-based problem? Dental Materials. 2015;31(11):e247-e77.

5. Demarco FF, Corrêa MB, Cenci MS, Moraes RR, Opdam NJM. Longevity of posterior composite restorations: Not only a matter of materials. Dental Materials. 2012;28(1):87-101.

6. Ferracane J, Hilton T, Stansbury J, Watts D, Silikas N, Ilie N, et al. Academy of Dental Materials guidance-Resin composites: Part II—Technique sensitivity (handling, polymerization, dimensional changes). Dental Materials. 2017;33(11):1171-91.

7. Lohbauer U, Zinelis S, Rahiotis C, Petschelt A, Eliades G. The effect of resin composite pre-heating on monomer conversion and polymerization shrinkage. Dental Materials. 2009;25(4):514-9.

8. Kaleem M, Satterthwaite JD, Watts DC. A method for assessing force/work 
parameters for stickiness of unset resin-composites. Dental Materials. 2011;27(8):805-10. 9. Kaleem M, Watts DC. Stiffness of uncured resin-composites assessed via cavitypacking forces. Dental Materials. 2016;32(9):e199-e203.

10. Al-Sharaa KA, Watts DC. Stickiness prior to setting of some light cured resincomposites. Dental Materials. 2003;19(3):182-7.

11. Ertl K, Graf A, Watts D, Schedle A. Stickiness of dental resin composite materials to steel, dentin and bonded dentin. Dental Materials. 2010;26(1):59-66.

12. Hoseney RC, Smewing JO. Instrumental Measurement of Stickiness of Doughs and Other Foods. Journal of Texture Studies. 2007;30(2):123-36.

13. Chuang $\mathrm{H}$, Chiu $\mathrm{C}$, Paniagua R. Avery adhesive test yields more performance data than traditional probe. Adhesives age. 1997;40(10):18-23.

14. Kaleem M, Satterthwaite JD, Watts DC. Effect of filler particle size and morphology on force/work parameters for stickiness of unset resin-composites. dental materials. 2009;25(12):1585-92.

15. Tyas MJ, Jones DW, Rizkalla AS. The evaluation of resin composite consistency. Dental Materials. 1998;14(6):424-8.

16. Silikas N, Watts D. Rheology of urethane dimethacrylate and diluent formulations. Dental Materials. 1999;15(4):257-61.

17. Lee J-H, Um C-M, Lee I-b. Rheological properties of resin composites according to variations in monomer and filler composition. Dental Materials. 2006;22(6):515-26.

18. Papakonstantinou AE, Eliades T, Cellesi F, Watts DC, Silikas N. Evaluation of UDMA's potential as a substitute for Bis-GMA in orthodontic adhesives. Dental Materials. 2013;29(8):898-905.

19. Gajewski VE, Pfeifer CS, Fróes-Salgado NR, Boaro LC, Braga RR. Monomers used in resin composites: degree of conversion, mechanical properties and water sorption/solubility. Brazilian dental journal. 2012;23(5):508-14.

20. Miletic V. Development of Dental Composites. Dental Composite Materials for Direct Restorations: Springer; 2018. p. 3-9.

21. Peutzfeldt A. Resin composites in dentistry: the monomer systems. European Journal of Oral Sciences. 1997;105(2):97-116.

22. Gonçalves F, Azevedo CL, Ferracane JL, Braga RR. BisGMA/TEGDMA ratio and filler content effects on shrinkage stress. Dental materials. 2011;27(6):520-6.

23. Lucey S, Lynch CD, Ray NJ, Burke FM, Hannigan A. Effect of pre-heating on the viscosity and microhardness of a resin composite. Journal of Oral Rehabilitation. 2010;37(4):278-82.

24. Lee I-B, Son H-H, Um C-M. Rheologic properties of flowable, conventional hybrid, and condensable composite resins. Dental Materials. 2003;19(4):298-307.

25. Blalock JS, Holmes RG, Rueggeberg FA. Effect of temperature on unpolymerized composite resin film thickness. Journal of Prosthetic Dentistry. 2006;96(6):424-32.

26. Deb S, Di Silvio L, Mackler HE, Millar BJ. Pre-warming of dental composites. Dental Materials. 2011;27(4):e51-e9.

27. SonicFill Portfolio of Scientific Research. Available from:

ftp://ftp.endoco.com/links/KerrSonicFillResearch.pdf.

28. Wagner W, Aksu M, Neme A, Linger J, Pink F, Walker S. Effect of pre-heating resin composite on restoration microleakage. Operative Dentistry. 2008;33(1):72-8.

29. Lempel E, Öri Z, Szalma J, Lovász BV, Kiss A, Tóth Á, et al. Effect of exposure time and pre-heating on the conversion degree of conventional, bulk-fill, fiber reinforced and polyacid-modified resin composites. Dental Materials. 2019;35(2):217-28.

30. Metalwala Z, Khoshroo K, Rasoulianboroujeni M, Tahriri M, Johnson A, Baeten J, et al. Rheological properties of contemporary nanohybrid dental resin composites: The influence of preheating. Polymer Testing. 2018;72:157-63.

31. Da Costa JB, Hilton TJ, Swift JEJ. Preheating Composites. Journal of Esthetic and Restorative Dentistry. 2011;23(4):269-75. 
32. Daronch M, Rueggeberg FA, Hall G, De Goes MF. Effect of composite temperature on in vitro intrapulpal temperature rise. Dental Materials. 2007;23(10):1283-8.

33. Tauböck TT, Tarle Z, Marovic D, Attin T. Pre-heating of high-viscosity bulk-fill resin composites: Effects on shrinkage force and monomer conversion. Journal of Dentistry. 2015;43(11):1358-64.

34. Nada K, El-Mowafy O. Effect of Precuring Warming on Mechanical Properties of Restorative Composites. International Journal of Dentistry. 2011;2011:5.

35. Daronch M, Rueggeberg FA, Moss L, De Goes MF. Clinically Relevant Issues Related to Preheating Composites. Journal of Esthetic and Restorative Dentistry. 2006;18(6):340-50.

36. Al-Qudah AA, Mitchell CA, Biagioni PA, Hussey DL. Thermographic investigation of contemporary resin-containing dental materials. Journal of Dentistry. 2005;33(7):593-

602 .

37. Bayne SC, Thompson JY, Swift EJJ, Stamatiades P, Wilkerson M. A

Characterization of First-Generation Flowable Composites. The Journal of the American

Dental Association. 1998;129(5):567-77.

38. Judeinstein P, Sanchez C. Hybrid organic-inorganic materials: a land of

multidisciplinarity. Journal of Materials Chemistry. 1996;6(4):511-25.

39. Moszner N, Salz U. New developments of polymeric dental composites. Progress in Polymer Science. 2001;26(4):535-76.

40. Cavalcante LM, Schneider LFJ, Silikas N, Watts DC. Surface integrity of solventchallenged ormocer-matrix composite. Dental Materials. 2011;27(2):173-9.

41. Scientific Compendium: Admira Fusion. Available from: http://212.227.148.121/epaper/scientific compendium/admira-fusion en/.

42. Kalachandra S, Sankarapandian M, Shobha HK, Taylor DF, McGrath JE. Influence of hydrogen bonding on properties of BIS-GMA analogues. Journal of Materials Science: Materials in Medicine. 1997;8(5):283-6.

43. Al-Ahdal K, Silikas N, Watts DC. Rheological properties of resin composites according to variations in composition and temperature. Dental Materials. 2014;30(5):51724.

44. Habib E, Wang R, Zhu XX. Correlation of resin viscosity and monomer conversion to filler particle size in dental composites. Dental Materials. 2018;34(10):1501-8.

45. TPH Spectra Universal Composite Restorative Science EN. Available from: https://www.dentsplysirona.com/content/dam/dentsply/pim/manufacturer/Restorative/Direc t Restoration/Composites Flowables/Universal_Composites/TPH_Spectra_Universal_Co mposite Restorative/TPH-Spectra-xnzlfpn-en-us-1402.

46. Tetric EvoCeram Instructions for Use. Available from:

http://downloads.ivoclarvivadent.com/zoolu-

website/media/document/827/Tetric+EvoCeram.

47. Filtek Supreme Ultra Technical Product Profile. Available from:

http://multimedia.3m.com/mws/media/629066O/filtektm-supreme-ultra-universalrestorative.pdf.

48. Al-Ahdal K, Ilie N, Silikas N, Watts DC. Polymerization kinetics and impact of post polymerization on the Degree of Conversion of bulk-fill resin-composite at clinically relevant depth. Dental Materials. 2015;31(10):1207-13.

49. Daronch M, Rueggeberg FA, De Goes MF, Giudici R. Polymerization Kinetics of Pre-heated Composite. Journal of Dental Research. 2006;85(1):38-43.

50. Trujillo M, Newman SM, Stansbury JW. Use of near-IR to monitor the influence of external heating on dental composite photopolymerization. Dental Materials.

2004;20(8):766-77. 
Table 1: Manufacturer information of investigated composites.

\begin{tabular}{lllllc}
\hline & Code & Manufacturer & Resin system & $\begin{array}{l}\text { Filler } \\
\text { vol.\% }\end{array}$ & $\begin{array}{c}\text { Filler } \\
\text { wt.\% }\end{array}$ \\
\hline $\begin{array}{l}\text { Admira } \\
\text { Fusion }\end{array}$ & AF & $\begin{array}{l}\text { VOCO, } \\
\text { Cuxhaven } \\
\text { Germany }\end{array}$ & ORMOCER $^{\circledR}$ & - & 84 \\
\hline $\begin{array}{l}\text { Filtek } \\
\text { Supreme } \\
\text { Ultra }\end{array}$ & FSU & $\begin{array}{l}\text { 3M ESPE, St. } \\
\text { Paul, USA }\end{array}$ & $\begin{array}{l}\text { bis-GMA, UDMA, } \\
\text { TEGDMA, bis-EMA }\end{array}$ & 63.3 & 78.5 \\
\hline TPH LV & TPH & $\begin{array}{l}\text { Dentsply, } \\
\text { Germany }\end{array}$ & $\begin{array}{l}\text { Urethane modified bis- } \\
\text { GMA, TEGDMA, } \\
\text { polymerizable } \\
\text { dimethacrylate }\end{array}$ & 54.6 & 75.5 \\
\hline $\begin{array}{l}\text { Tetric } \\
\text { EvoCeram }\end{array}$ & TEC & $\begin{array}{l}\text { Ivoclar } \\
\text { Vivadent, USA }\end{array}$ & $\begin{array}{l}\text { bis-GMA, urethane } \\
\text { dimethacrylate, bis- } \\
\text { EMA }\end{array}$ & 54 & 75 \\
\hline Harmonize & HZ & Kerr, USA & $\begin{array}{l}\text { bis-GMA, bis-EMA, } \\
\text { TEGDMA }\end{array}$ & 64.5 & 81 \\
\hline Viscalor & VC & $\begin{array}{l}\text { VOCO, } \\
\text { Cuxhaven } \\
\text { Germany }\end{array}$ & $\begin{array}{l}\text { bis-GMA, aliphatic } \\
\text { dimethacrylate }\end{array}$ & - & 83 \\
\hline
\end{tabular}

Table 2: Extrusion force $(\mathrm{N})$ and the mass of extruded composite $(\mathrm{g})$ of new/half-used Viscalor compule (no heat, T3-30s and T3-3min).

\begin{tabular}{ccccc}
\hline \multirow{2}{*}{ Materials } & \multicolumn{2}{c}{ Force $(\mathrm{N})$} & \multicolumn{2}{c}{ Mass $(\mathrm{g})$} \\
\cline { 3 - 6 } & $\mathrm{New}$ & Half-used & New & Half-used \\
\hline Viscalor & $153.62^{\mathrm{a} A}$ & $152.40^{\mathrm{a} \mathrm{A}}$ & $0.0055^{\mathrm{a} \mathrm{B}}$ & $0.0134^{\mathrm{a} C}$ \\
(no heat) & $(1.56)$ & $(2.38)$ & $(0.00)$ & $(0.00)$ \\
\hline Viscalor & $145.45^{\mathrm{a} \mathrm{A}}$ & $150.59^{\mathrm{a} \mathrm{A}}$ & $0.1028^{\mathrm{b} \mathrm{B}}$ & $0.2261^{\mathrm{bC}}$ \\
(T3-30s) & $(8.15)$ & $(0.36)$ & $(0.04)$ & $(0.01)$ \\
\hline Viscalor & $66.49^{\mathrm{b} \mathrm{A}}$ & $51.29^{\mathrm{b} \mathrm{A}}$ & $0.1756^{\mathrm{b} \mathrm{B}}$ & $0.2834^{\mathrm{c} \mathrm{C}}$ \\
(T3-3min) & $(14.16)$ & $(11.93)$ & $(0.04)$ & $(0.02)$ \\
\hline
\end{tabular}


Table 3: Stickiness parameters: $F_{\max }(\mathrm{N})$ and $\mathrm{W}_{\mathrm{s}}\left(\mathrm{N}\right.$ mm), and packability, $\mathrm{F}_{\mathrm{p}}(\mathrm{N})$ at 22 and $37^{\circ} \mathrm{C}$.

\begin{tabular}{|c|c|c|c|c|c|c|}
\hline \multirow{2}{*}{ Materials } & \multicolumn{2}{|c|}{$F_{\max }(\mathrm{N})$} & \multicolumn{2}{|c|}{$\mathrm{W}_{\mathrm{s}}(\mathrm{N} \mathrm{mm})$} & \multicolumn{2}{|c|}{$F_{p}(N)$} \\
\hline & $22^{\circ} \mathrm{C}$ & $37^{\circ} \mathrm{C}$ & $22^{\circ} \mathrm{C}$ & $37^{\circ} \mathrm{C}$ & $22^{\circ} \mathrm{C}$ & $37^{\circ} \mathrm{C}$ \\
\hline Admira & $3.28^{\mathrm{f} \mathrm{A}}$ & $3.12^{\mathrm{d} A}$ & $2.12^{\mathrm{d} \mathrm{A}}$ & $3.61^{\mathrm{d} \mathrm{A}}$ & $41.56^{\mathrm{fC}}$ & $23.09^{\mathrm{e} B}$ \\
\hline Fusion & $(0.10)$ & $(0.08)$ & $(0.22)$ & (0.97) & (1.77) & (1.00) \\
\hline Filtek & $2.94^{\mathrm{e} B}$ & $2.07^{\mathrm{c} \mathrm{A}, \mathrm{B}}$ & $1.26^{\mathrm{b}, \mathrm{c} \mathrm{A}}$ & $0.97^{\mathrm{a} \mathrm{A}}$ & $27.11^{\mathrm{b} D}$ & $19.40^{\mathrm{d} \mathrm{C}}$ \\
\hline $\begin{array}{l}\text { Supreme } \\
\text { Ultra }\end{array}$ & $(0.04)$ & $(0.02)$ & $(0.09)$ & $(0.09)$ & $(0.91)$ & (1.66) \\
\hline \multirow{2}{*}{ TPH LV } & $1.91^{\mathrm{a} \mathrm{A}}$ & $1.50^{\mathrm{a} \mathrm{A}}$ & $0.88^{\mathrm{a}, \mathrm{b} \mathrm{A}}$ & $1.30^{\mathrm{a}, \mathrm{b} \mathrm{A}}$ & $24.10^{\mathrm{a} C}$ & $10.79^{\mathrm{a} B}$ \\
\hline & $(0.06)$ & $(0.14)$ & $(0.03)$ & $(0.17)$ & $(0.62)$ & (1.14) \\
\hline Tetric & $2.86^{\mathrm{d}, \mathrm{e} C}$ & $2.21^{\mathrm{c} \mathrm{B}, \mathrm{C}}$ & $0.79^{\mathrm{a} \mathrm{A}}$ & $1.29^{\mathrm{a}, \mathrm{b} \mathrm{A}, \mathrm{B}}$ & $32.30^{\mathrm{c}, \mathrm{d} E}$ & $16.64^{\mathrm{cD}}$ \\
\hline EvoCeram & $(0.04)$ & $(0.11)$ & $(0.06)$ & $(0.15)$ & $(1.24)$ & $(0.40)$ \\
\hline \multirow{2}{*}{ Harmonize } & $2.51^{\mathrm{b}, \mathrm{c} \mathrm{A}}$ & $1.70^{\mathrm{bA}}$ & $1.04^{\mathrm{a}, \mathrm{b}, \mathrm{c} A}$ & $2.03^{\mathrm{c} \mathrm{A}}$ & $35.75^{\mathrm{eC}}$ & $15.08^{\mathrm{b}, \mathrm{c} \mathrm{B}}$ \\
\hline & $(0.04)$ & $(0.06)$ & $(0.04)$ & $(0.13)$ & $(2.86)$ & (1.68) \\
\hline \multirow{2}{*}{$\begin{array}{l}\text { Viscalor } \\
\text { (no heat) }\end{array}$} & $3.03^{\mathrm{e} B}$ & $2.19^{\mathrm{c} \mathrm{A}, \mathrm{B}}$ & $1.42^{\mathrm{c} \mathrm{A}}$ & $2.35^{\mathrm{c} \mathrm{A}, \mathrm{B}}$ & $31.88^{\mathrm{c}, \mathrm{d} D}$ & $15.46^{\mathrm{b}, \mathrm{c} C}$ \\
\hline & $(0.21)$ & $(0.07)$ & $(0.23)$ & $(0.13)$ & $(0.66)$ & $(1.01)$ \\
\hline \multirow{2}{*}{$\begin{array}{l}\text { Viscalor } \\
\text { (T3-30s) }\end{array}$} & $2.67^{\mathrm{c}, \mathrm{d} \mathrm{A}}$ & $2.17^{\mathrm{c} \mathrm{A}}$ & $2.62^{\mathrm{eA}}$ & $1.71^{\mathrm{b}, \mathrm{c} \mathrm{A}}$ & $29.58^{\mathrm{b}, \mathrm{c} C}$ & $14.13^{\mathrm{b} \mathrm{B}}$ \\
\hline & $(0.08)$ & $(0.08)$ & $(0.21)$ & $(0.12)$ & (1.18) & (0.99) \\
\hline \multirow{2}{*}{$\begin{array}{c}\text { Viscalor } \\
\text { (T3-3min) }\end{array}$} & $2.39^{\mathrm{b} \mathrm{A}}$ & $2.19^{\mathrm{c} \mathrm{A}}$ & $1.89^{\mathrm{d} A}$ & $4.69^{\mathrm{e} B}$ & $34.55^{\text {d,e D }}$ & $16.39^{\mathrm{b}, \mathrm{c} C}$ \\
\hline & (0.09) & $(0.11)$ & $(0.36)$ & $(0.60)$ & $(0.17)$ & $(0.17)$ \\
\hline \multicolumn{7}{|c|}{$\begin{array}{l}\text { For each temperature, similar lower case superscript letters indicate homogeneous } \\
\text { subsets among the materials. For each material, similar CAPITAL superscript letters } \\
\text { indicate homogeneous subsets among different conditions. }\end{array}$} \\
\hline
\end{tabular}

Table 4: Degree of conversion of Viscalor (no heat, T3-30s and T3-3min) at $5 \mathrm{~min}$ and $24 \mathrm{~h}$ post cure $\left(\mathrm{DC}_{5 \min }\right.$ and $\left.\mathrm{DC}_{24 \mathrm{~h}}\right)$.

\begin{tabular}{|c|c|c|c|c|}
\hline \multirow{2}{*}{ Materials } & \multicolumn{2}{|c|}{ Syringe } & \multicolumn{2}{|c|}{ Compule } \\
\hline & $\mathrm{DC}_{5 \min }$ & $\mathrm{DC}_{24 \mathrm{~h}}$ & $\mathrm{DC}_{5 \min }$ & $\mathrm{DC}_{24 \mathrm{~h}}$ \\
\hline $\begin{array}{l}\text { Viscalor } \\
\text { (no heat) }\end{array}$ & $\begin{array}{c}40.78 \% \%^{\mathrm{a} \mathrm{A}} \\
(0.01)\end{array}$ & $\begin{array}{c}58.04 \% \%^{\mathrm{a} \mathrm{B}} \\
(0.03)\end{array}$ & $\begin{array}{c}41.99 \%^{\mathrm{aA}} \\
(0.01)\end{array}$ & $\begin{array}{c}60.17 \% \%^{\mathrm{a} \mathrm{B}} \\
(0.03)\end{array}$ \\
\hline $\begin{array}{l}\text { Viscalor } \\
\text { (T3-30s) }\end{array}$ & $\begin{array}{c}42.77 \%{ }^{\mathrm{a} \mathrm{A}} \\
(0.01)\end{array}$ & $\begin{array}{c}58.49 \%^{\mathrm{a} B} \\
(0.01)\end{array}$ & $\begin{array}{c}42.76 \%^{\mathrm{a} \mathrm{A}} \\
(0.01)\end{array}$ & $\begin{array}{c}58.88 \% \%^{\mathrm{a} \mathrm{B}} \\
(0.01)\end{array}$ \\
\hline $\begin{array}{c}\text { Viscalor } \\
\text { (T3-3min) }\end{array}$ & $\begin{array}{c}40.71 \%^{\mathrm{aA}} \\
(0.01)\end{array}$ & $\begin{array}{c}58.30 \%{ }^{\mathrm{a} \mathrm{B}} \\
(0.01)\end{array}$ & $\begin{array}{c}41.65 \%^{\mathrm{aA}} \\
(0.00)\end{array}$ & $\begin{array}{c}60.60 \% \%^{\mathrm{aC}} \\
(0.01)\end{array}$ \\
\hline \multicolumn{5}{|c|}{$\begin{array}{l}\text { For each DC, similar lower case superscript letters indicate } \\
\text { homogeneous subsets among the materials. For each material, } \\
\text { similar CAPITAL superscript letters indicate homogeneous subsets } \\
\text { among different conditions. }\end{array}$} \\
\hline
\end{tabular}




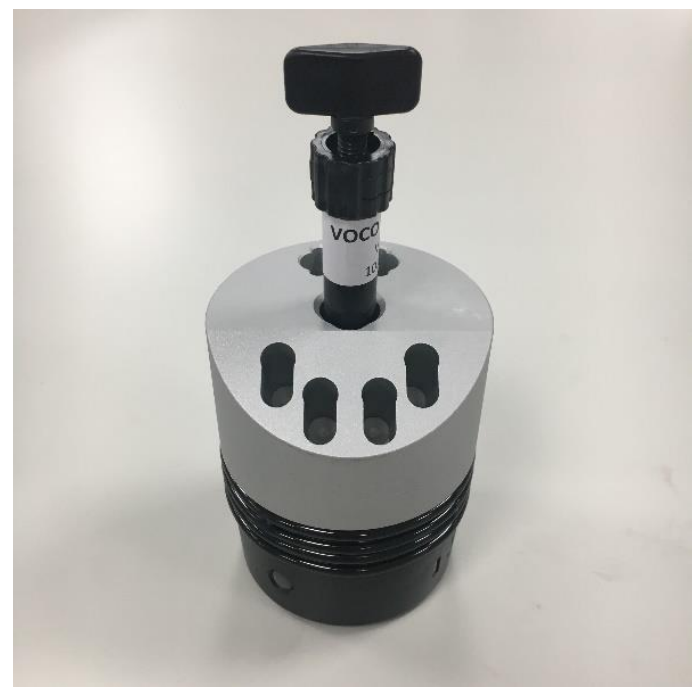

Figure S1: Caps Warmer (VOCO, Cuxhaven, Germany).

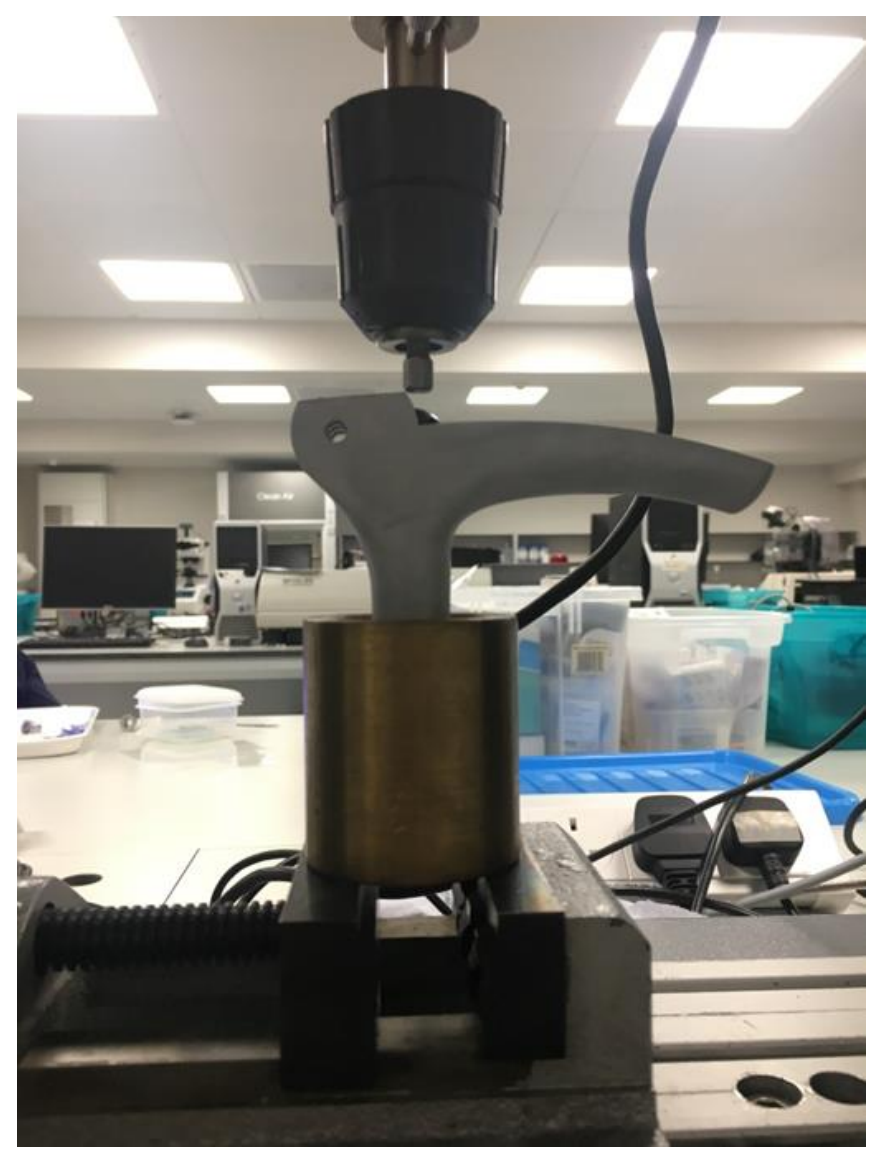

Figure S2: Extrusion measurement setup. 


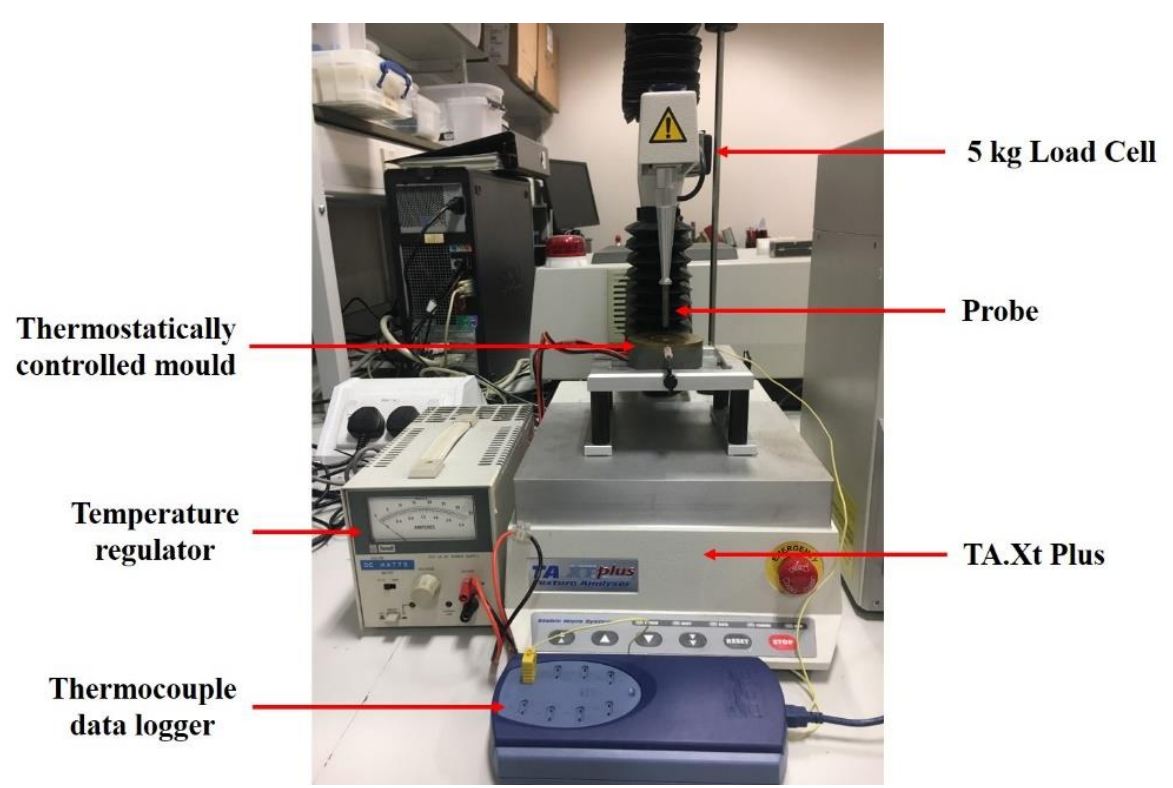

Figure S3: Experimental setup for stickiness and packability measurement.

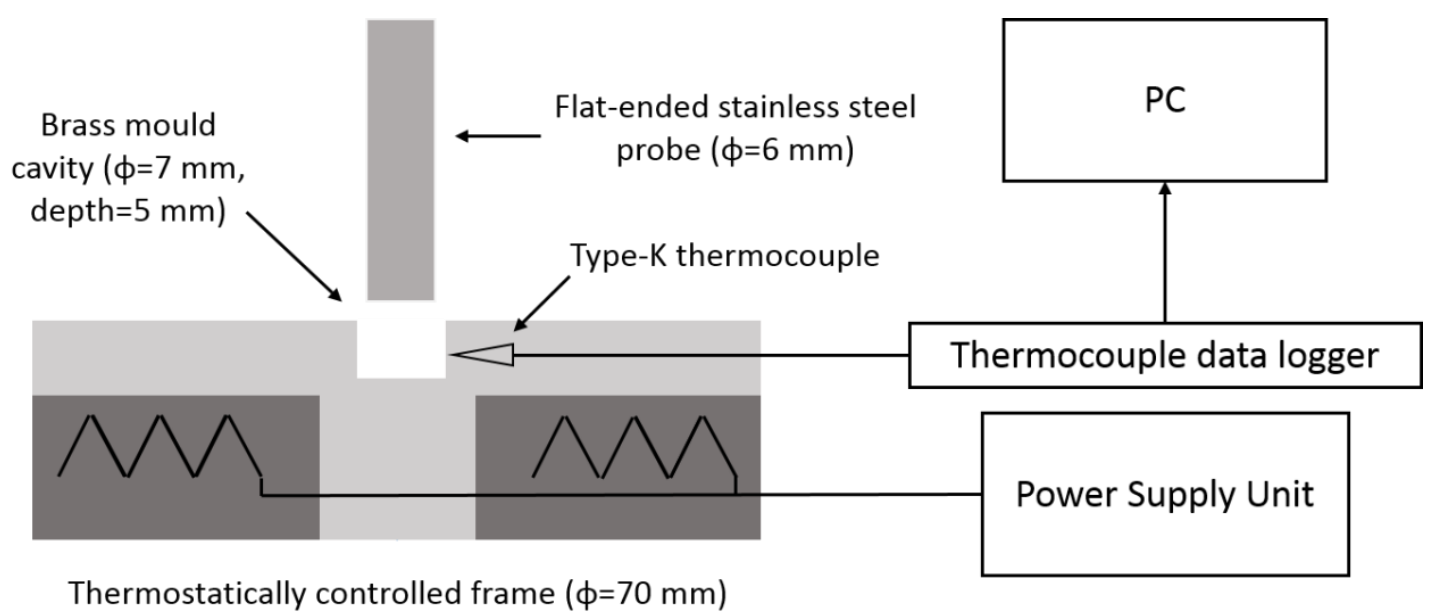

Figure 1: Mold setup with temperature regulation. 


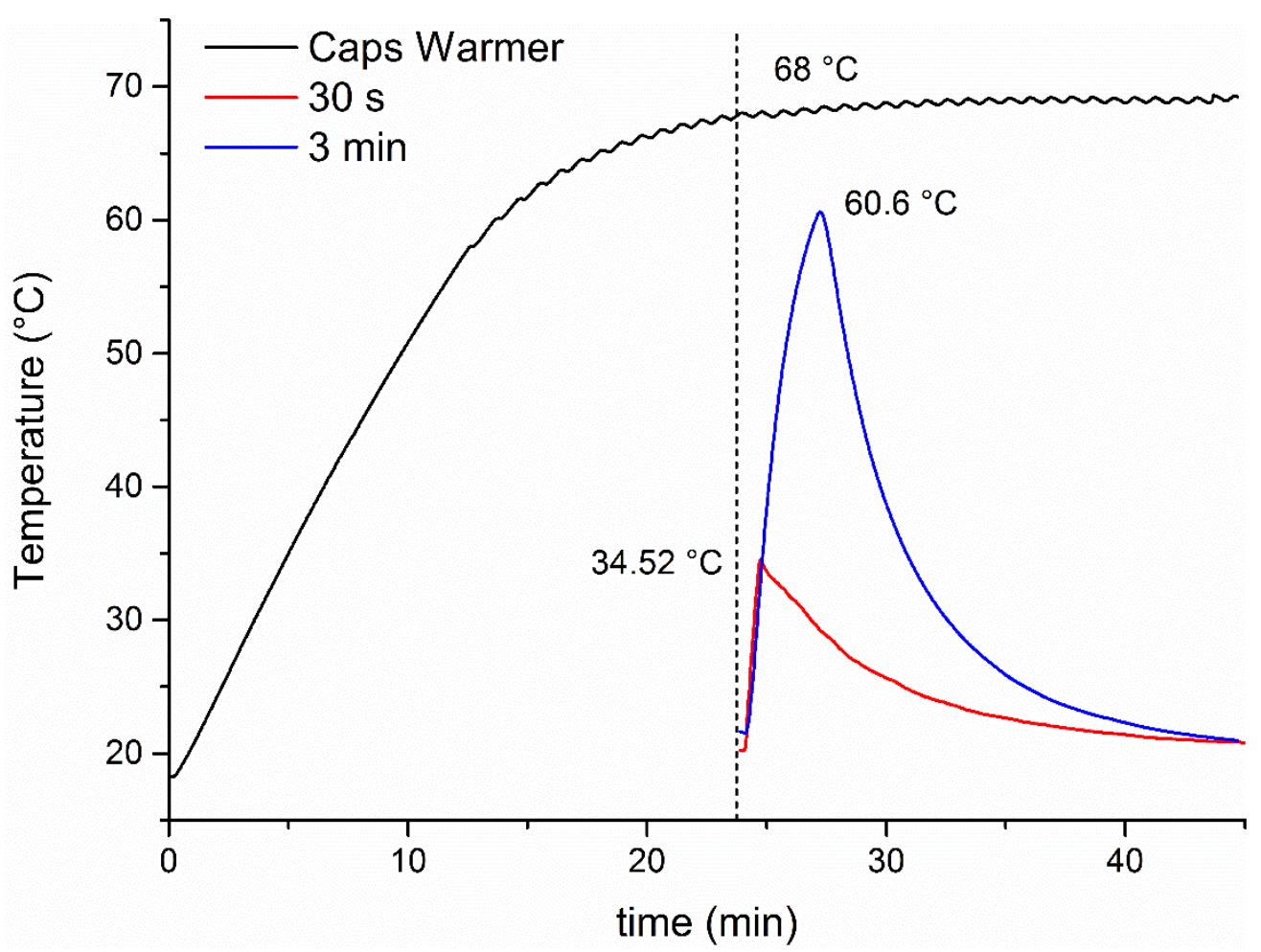

Figure 2: Representative temperature/time profiles of Caps Warmer (T3 mode) and Viscalor following pre-heating for different time periods.

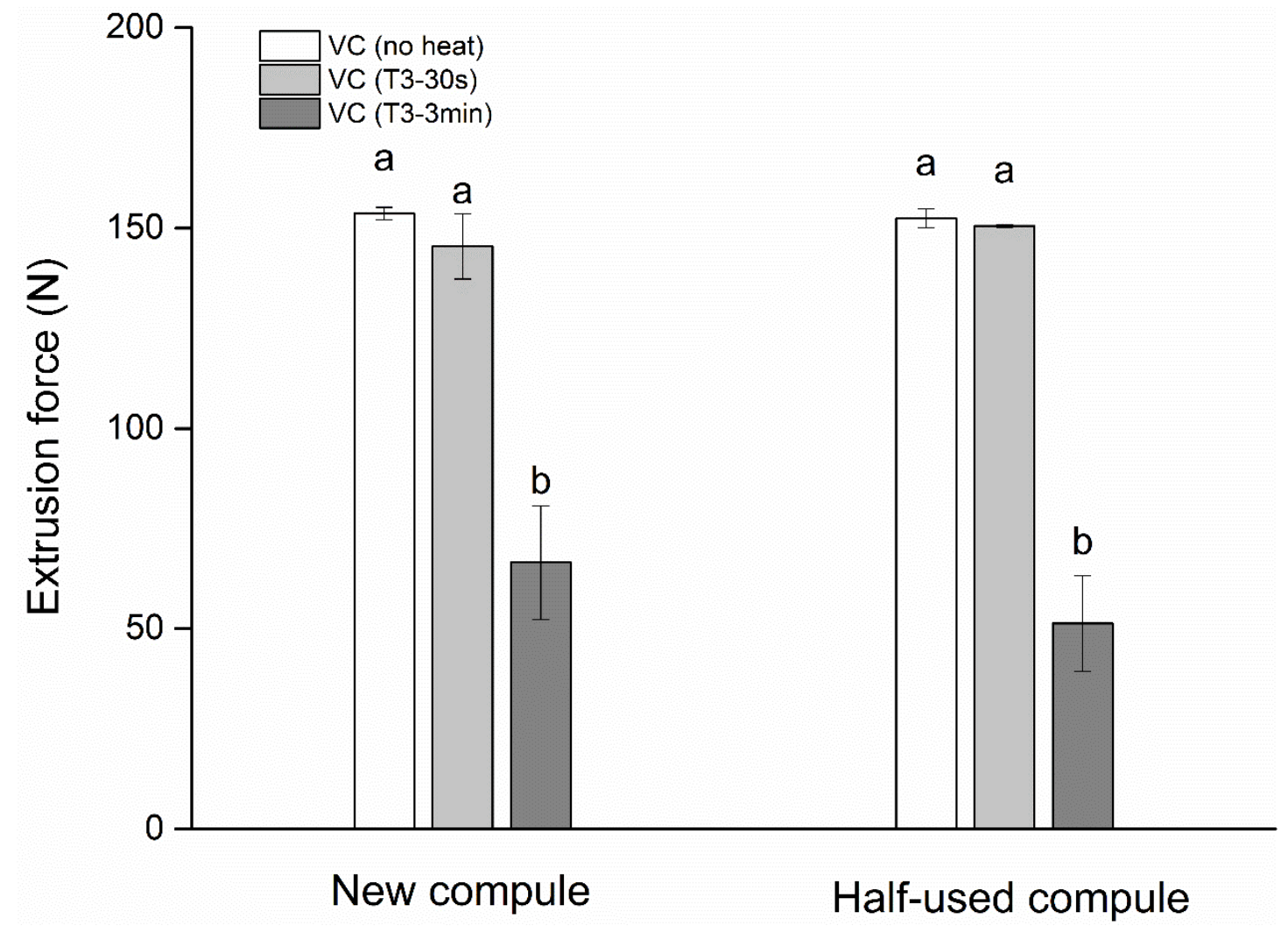

Figure 3: Extrusion force (N) of new/half-used Viscalor compule (no heat, T3-30s and T3$3 \mathrm{~min})$. 


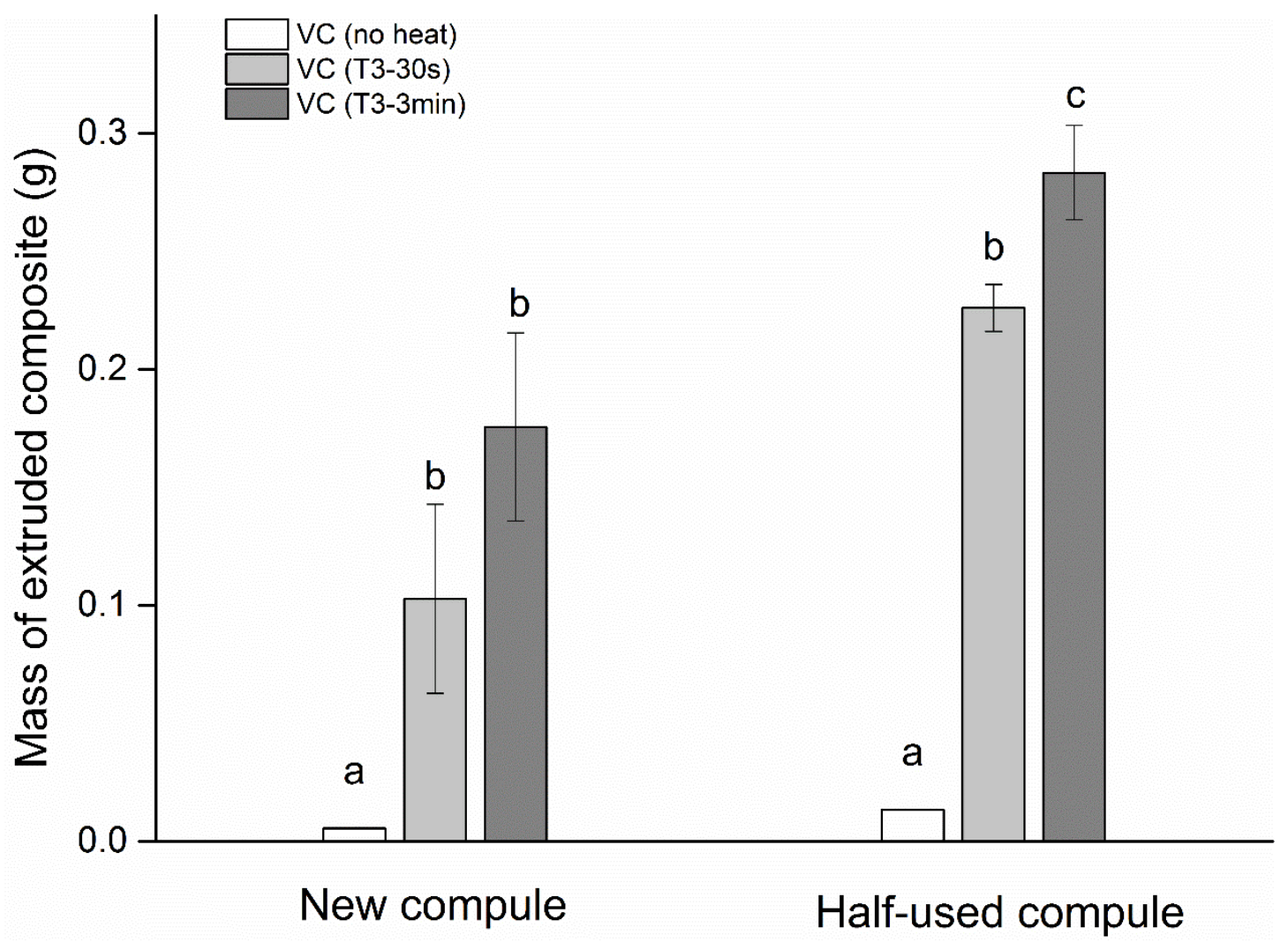

Figure 4: Mass of extruded composite (g) of new/half-used Viscalor compule (no heat, T3$30 \mathrm{~s}$ and $\mathrm{T} 3-3 \mathrm{~min})$.

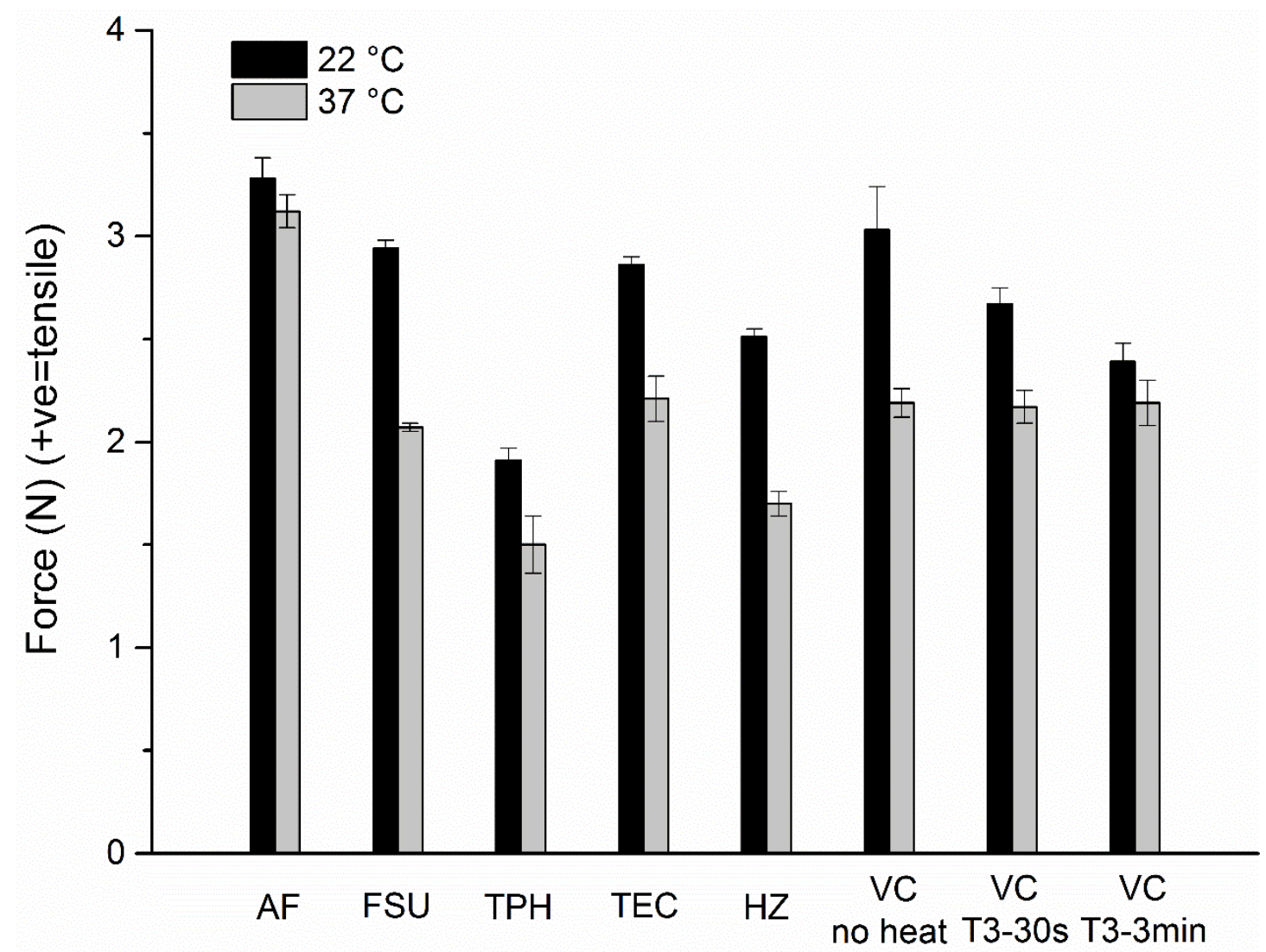

Figure 5: Maximum separation force $\left(\mathrm{F}_{\max }\right)$ of investigated composites at 22 and $37^{\circ} \mathrm{C}$. 


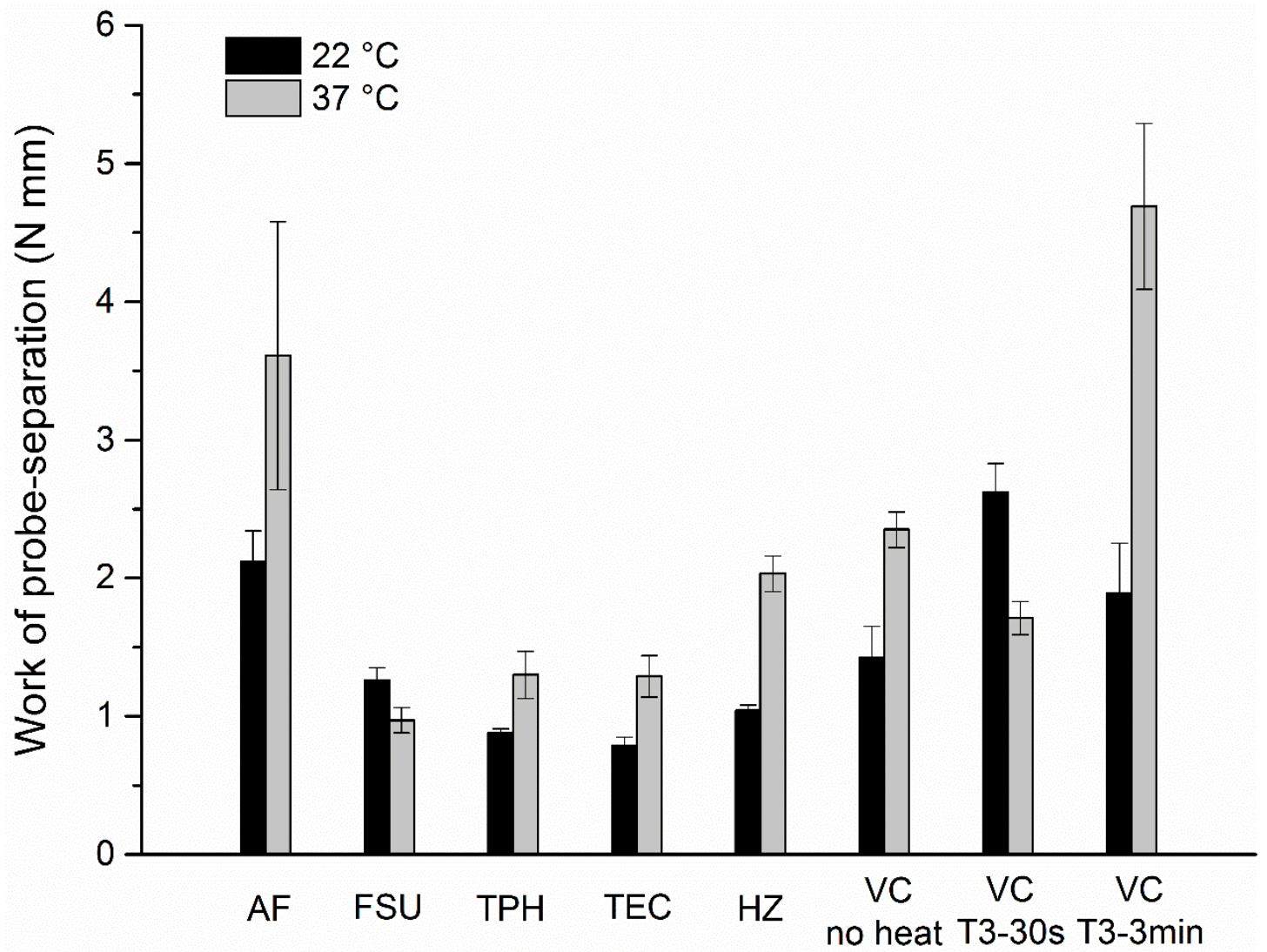

Figure 6: Work of probe-separation $\left(\mathrm{W}_{\mathrm{s}}\right)$ of investigated composites at 22 and $37^{\circ} \mathrm{C}$.

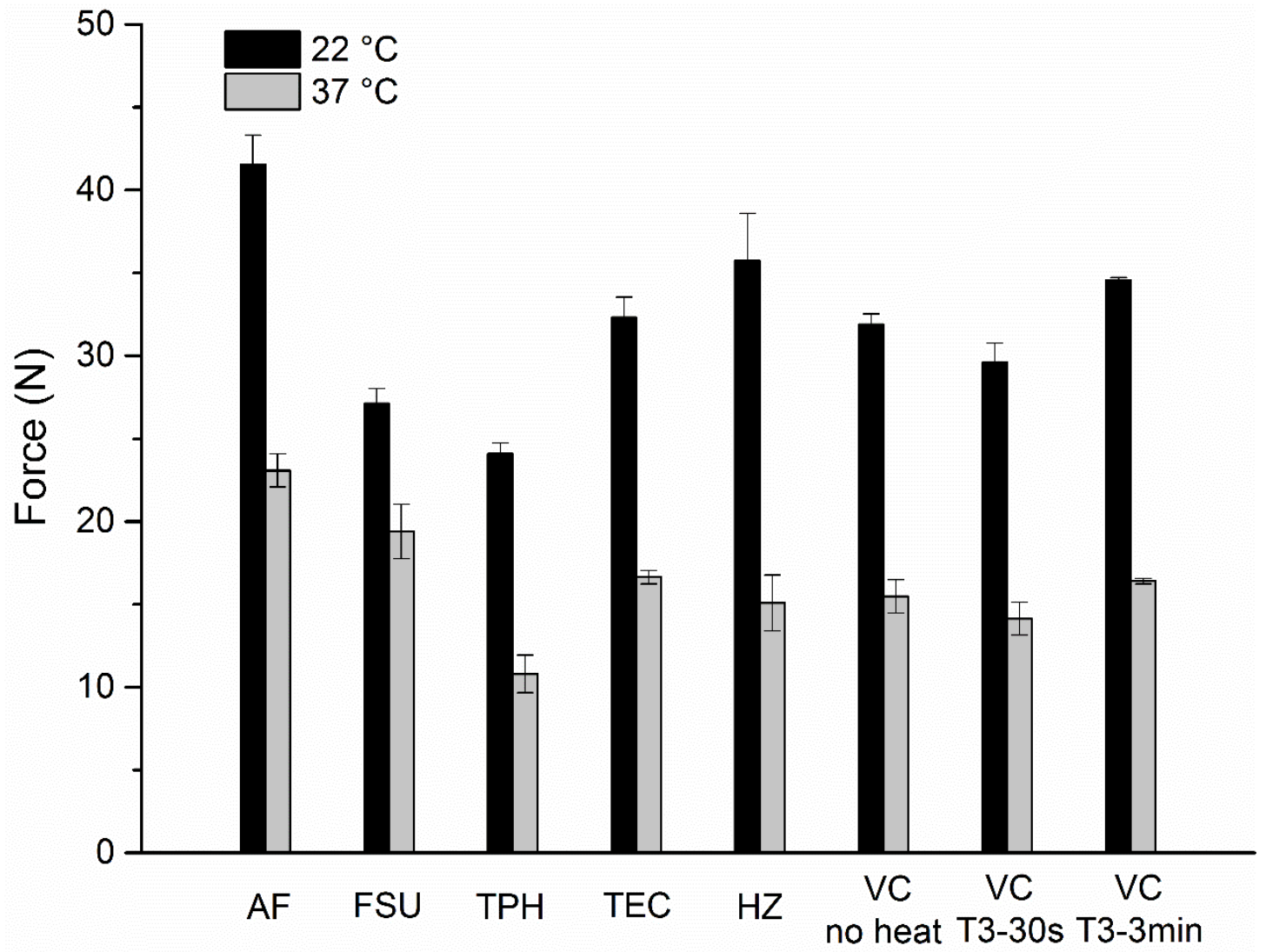

Figure 7: Maximum packing force $\left(\mathrm{F}_{\mathrm{p}}\right)$ of investigated composites at 22 and $37{ }^{\circ} \mathrm{C}$. 


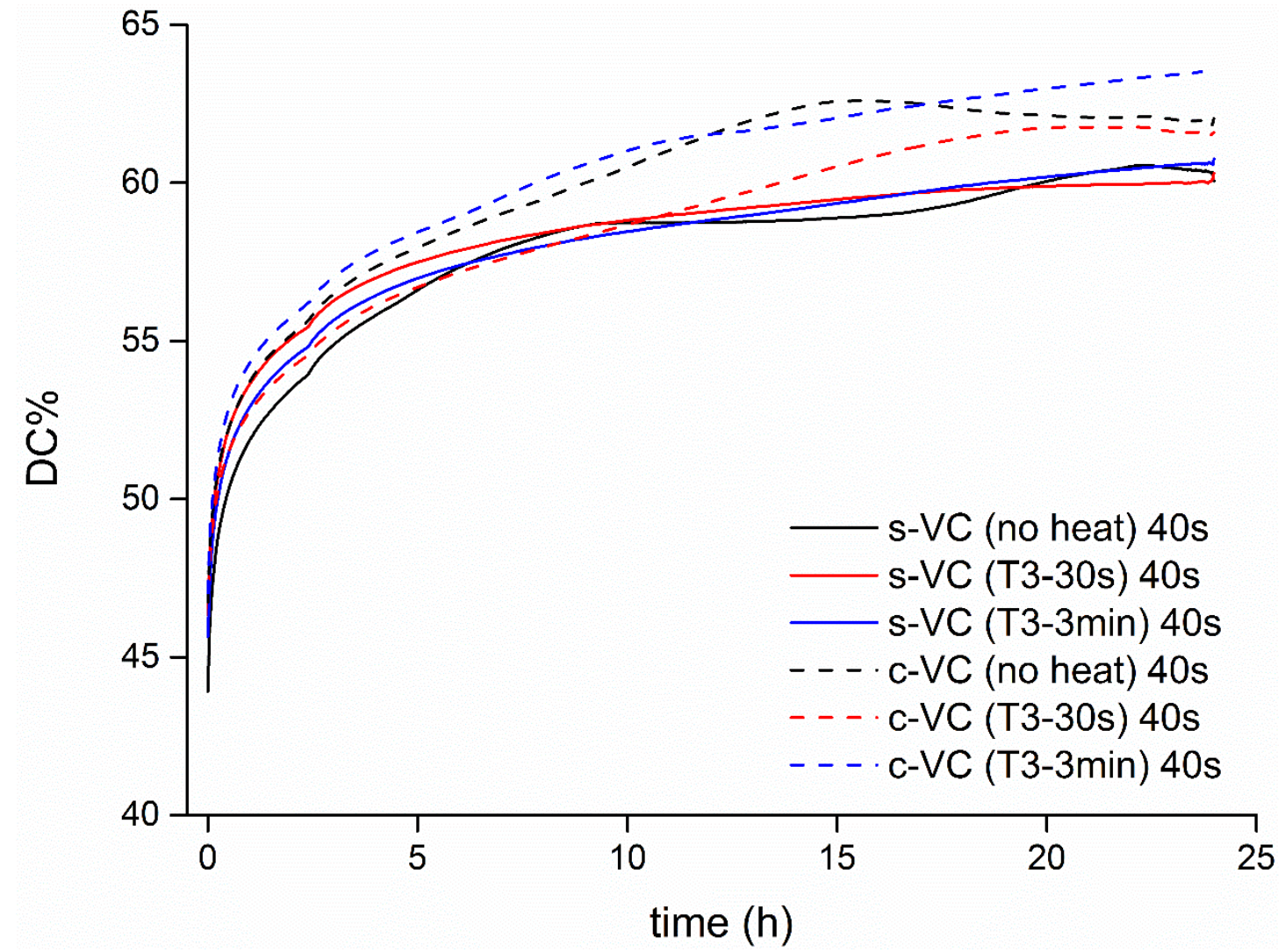

Figure 8: Real-time DC\% vs. time during $24 \mathrm{~h}$ post-polymerization for Viscalor syringe/compule (no heat, T3-30s, T3-3min).

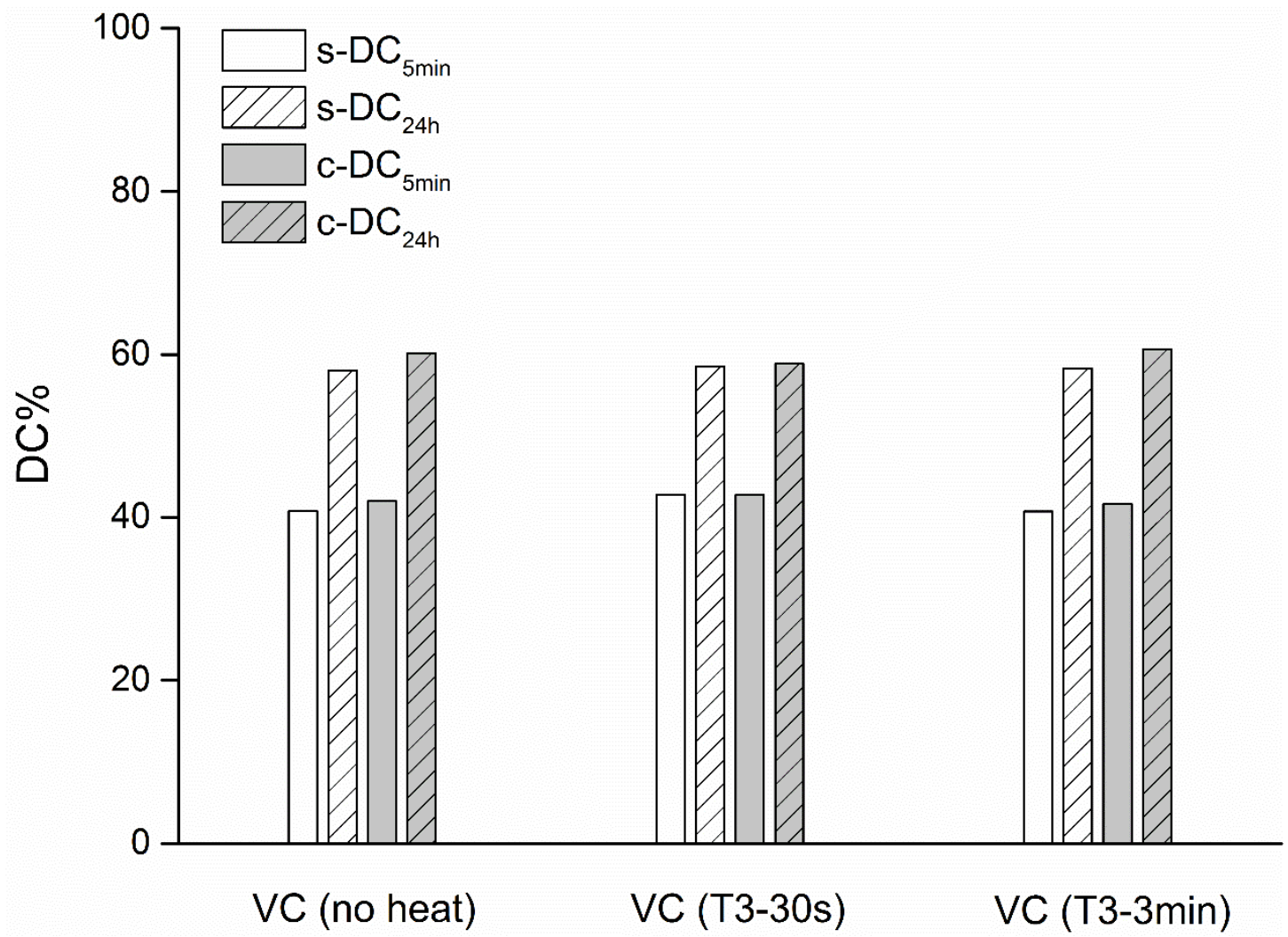

Figure 9: DC\% results of Viscalor syringe/compule (no heat, T3-30s and T3-3min) at 5 min and $24 \mathrm{~h}$ post cure $\left(\mathrm{DC}_{5 \mathrm{~min}}\right.$ and $\left.\mathrm{DC}_{24 \mathrm{~h}}\right)$. 


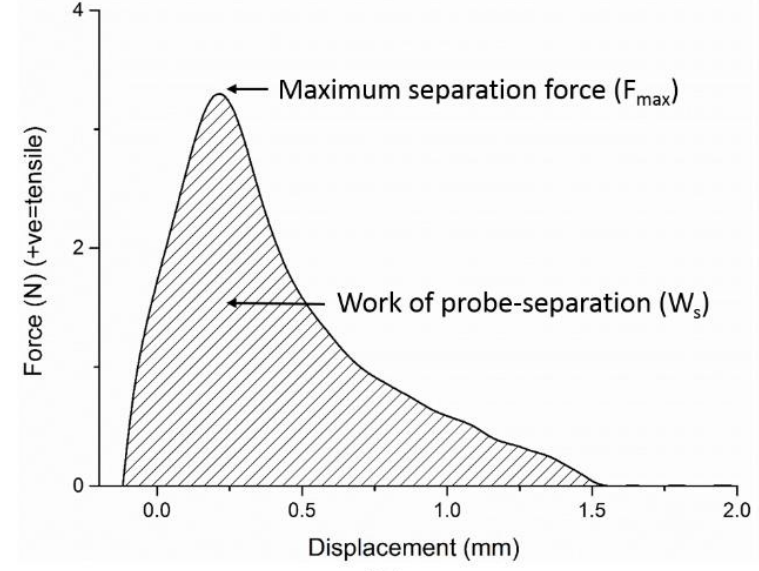

(a)

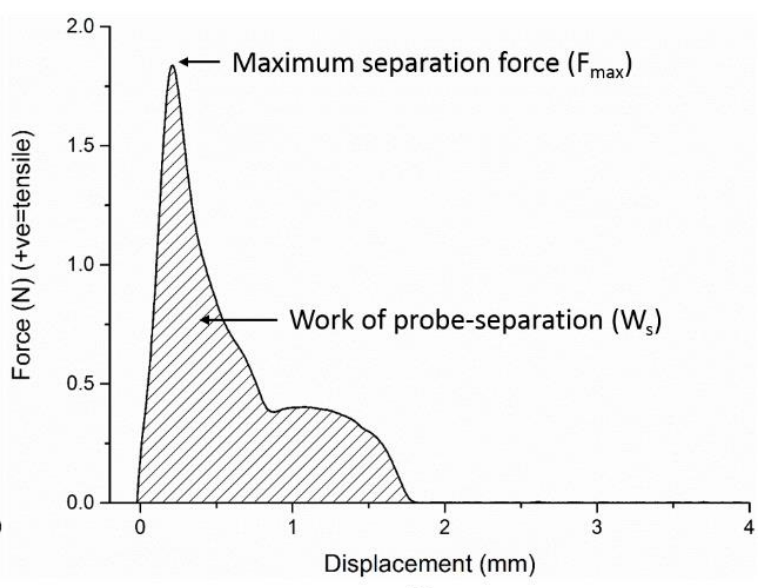

(b)

Figure S4: (a) Type I force/displacement curve, and (b) Type II force/displacement curve during stickiness measurement.

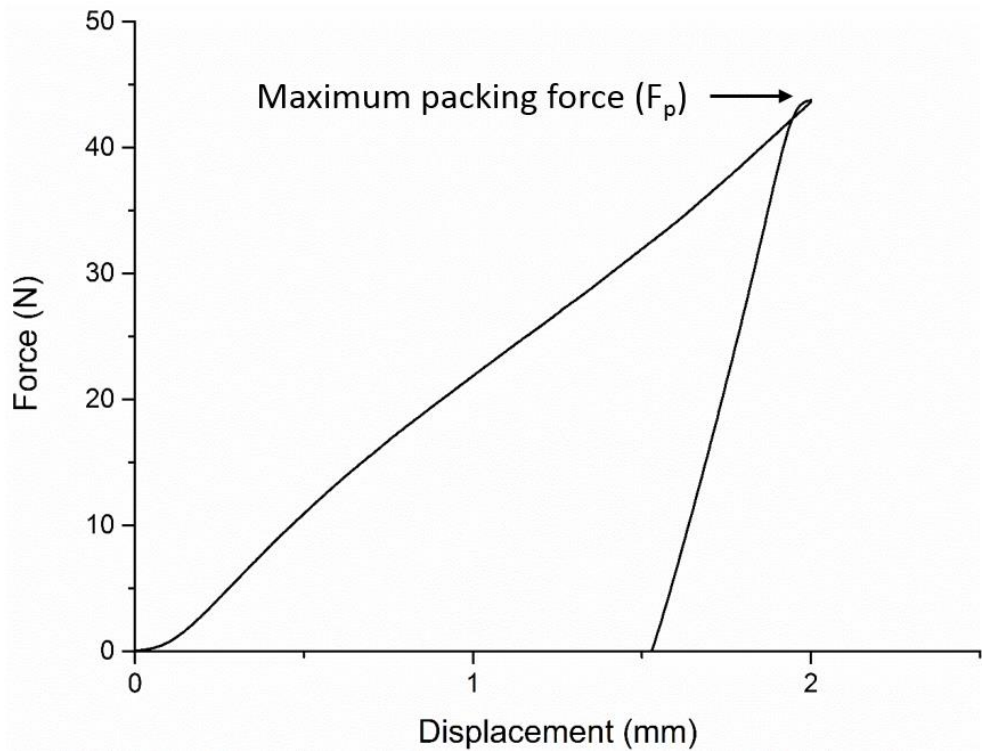

Figure S5: Typical force/displacement curve during packability measurement. 